\title{
Linguo-Statistical Analysis of Borrowed Words Used in School Textbooks and Children's Literature Books
}

\section{Summary \\ Introduction}

Pre-primary school and basic educational programmes pay attention to children's speech development, combining it with vocabulary development and acquisition of words meaning.

As early as in kindergarten, favourable opportunities should be provided for the development of literary correct and rich language, and non-literate words should be eliminated from children's speech. The kindergarten curriculum claims that at the preschool age, children must acquire such a vocabulary, which can ensure communication by means of language, prepare them for successful learning at school, and foster perception offolklore, fiction, films, radio and TV programmes. While children are learning the language, words from their passive vocabulary can enter the active vocabulary, depending on the work done for language enrichment by adults. A very important task to be implemented by both parents and teachers is to open up the wealth of the literary language, which can be perceived through multiple sources - folksongs, fairytales, legends, proverbs, sayings, riddles. A major role is played by fiction in the process of personality development, because it immensely facilitates children's knowledge about the environment, adult and peers life, and about their ideas, actions and aspirations.

Diminutives, exclamation words and sound verbs, serving efficiently for short emotional description of feelings, volition or reality and expressing their assessment, are widely involved by both adults and children in their language as well as used in genres of folklore and children literature.

Children have to be able to use comparisons, synonyms, idioms, and foreign words, because in daily speech they are an integral components (they are widespread in fiction and in other styles, different language fields). Loan words help to acquire foreign language more easily, approach languages and promote understanding.

\section{Aim of the study}

The aim of this work is to discover the usage of foreign words in textbooks for primary schools because foreign words are crucial components of vocabulary.

\section{Materials and methods}

School textbooks, children's literature. Methods of applied linguastatistics, descriptive method and testing.

\section{Results}

As figures of statistics show there are quite a lot of foreign words which are used in textbooks for children in primary classes. Teachers think that a limited number of foreign words should be included in textbooks.

\section{Conclusions}

Primary attention at the teachers' studies courses is paid to teaching foreign methodology.

Key words: school textbooks, children literature, borrowed words, linguastatistical analysis.

\section{Introduction}

Preschool and basic educational programmes pay significant attention to children's speech development, combining it with vocabulary development (Kañepēja 2003, 58) of acquisition of words meaning (especially of borrowings) and their comprehension, the maintenance of correct phoneme pronunciation, development of grammatically correct speech. As early as in kindergarten, favourable opportunities should be provided for the development of literary correct and rich language, nonliterate words should be purposefully eliminated from children's speech (Kuzina 2006, 260). The kindergarten curriculum claims that at preschool age the child must acquire a vocabulary which can 
ensure communication by means of the language, prepare them for successful learning at school, foster perception of folklore, fiction, films, radio and TV programmes.

A very important task to be implemented by both parents and teachers is to introduce borrowed words (i. e. foreign words), which constitute an important component of the lexicon (widespread in fiction and other styles, other areas of language); meanwhile they considerably enrich children's vocabulary and by their widespread usage make easier the acquisition of other languages; thus, the children should not avoid using such words.

Borrowings penetrate into any language under the influence of various cultural, political, economical and other conditions; therefore, adult and child language, fiction, scientific literature etc. includes such words and word combinations, which express conceptions in science, technology and art.

\section{Aim of the study}

The article has been created due to the project 'Children language research in Latvia: linguistic, social and culture aspects.'The article pays major attention to the usage of borrowed foreign words (also barbarisms) in textbooks for forms 1 and 2 in primary schools, children literature and in the children language.

\section{Materials and methods}

The article analyses four text-books, which are proposed for schools with Latvian as the language of instruction. The research has implemented linguo-statistical and descriptive methods, questionnaires, and interviews.

\section{Results}

Each of us uses words borrowed from other languages that have come into Latvian everyday language. Many of them denote widespread conceptions, for instance, radio, television, cars, balcony, ticket, price etc. The greatest number of borrowings (loans) or international words has been introduced from words of Greek and Latin origin, known both by large and small nations, for instance, alphabet, ball, grammar, idea, climate, choir, lexicon, machine, theatre, museum, metal, author, examination, excursion, class, confectionery, furniture, mode, person, reconstruction, republic etc.

Due to historical conditions, the Latvian language is most influenced by German and Russian languages (recently - by the English language), yet their own footprints have also been left by other (French, Italian etc.) languages.

The entry of loans into the Latvian language and other languages is a natural process, because due to them, the vocabulary of any language is considerably enriched. As recognized by the majority of linguists, the full value existence of the Latvian language nowadays cannot be exercised without such loans as aktieris, alfabèts, banāns, klase, koncerts, mode, mašīna, opera, šokolāde, tramvajs, trolejbuss etc. borrowed during the last centuries or even recent years. In this respect we must agree with P. Birznieks that the Latvian language should not be afraid of invasion by foreign words and foreign syntactic forms; it should be afraid only of the native speakers who lack diligence and show no respect to the flourishing of their language (Birznieks 1996, 148).

As known, a part of international words (i. e., loans, which are known in many languages) have their equivalents in the Latvian language (for instance, stabils - noturïgs, unikäls - vienreizígs, komplicēts sarežgi ìts, realizèt - istenot, ignorēt - neievērot etc.), which widen the opportunities of expressing, bestow the language with flexibility, precision, create stylistic diversity. In some respect, the use of these words in speech or written works disclose the person's broadness of perception, his intelligence; therefore, parents' and teachers' task is to promote gradual enrichment of children's language with foreign words.

The majority of international words have to be acquired consciously, as memorisation of their meanings requires special attention. When encountering some less known international words, children 
should try to remember the words with the same root, perceiving the word-building connections, for instance, pretendēt, pretendents; kandidēt, kandidāts, etc. Thus, single words will not exist as isolated items, but will constitute units of related words like the Latvian origin words possessing the same root.

To illustrate the usage of foreign words in the text-books (for forms 1 and 2), it is necessary to mention some figures:

Form 1 text-book includes 5\% foreign words;

Form 2 text-book includes $8 \%$ foreign words.

As foreign words also constitute a significant part of everyday vocabulary, it is advisable to enrich the children's vocabulary regularly at first with the most often used foreign words (international words), meanwhile explaining their meanings in accordance with the children's development level. Parents, preschool and basic school teachers, radio, television and mass media officers can assist children in acquiring foreign words (also the more rarely used). It is important for the teachers pay attention to the correct use of foreign words (for instance, getras, fliterïtis, panno, figüra, elements etc.).

Very often the play-games as well as the text-book texts include sentences, which involve even several foreign words, for instance, Nolikt kvadrātinu uz analoga kvadrātina, Noklāt laukuma katru otro sleju: horizontāli, vertikāli, pa diagonāli, šaha veidā, Automātiskais šoferis bez grūtībām iedarbina motoru, Materiāli no "Lielās ilustrētās enciklopēdijas", Mūsdienās kosmosā strādā orbitālās stacijas, kas tur darbojas pat vairākus gadus, un tās apmeklē vairākas astronautu komandas, Ekskursijā uz Rïgas motormuzeju 2. klases skolēni brauca ar autobusu utt. Also Form 2 text-book in one text on the Olympic Games (also in comments) there are as many as 20 foreign words (olimpiskais, talismans, simbolizèt, ceremonija, kontinents, stafete, komiteja, prezidents, olimpiāde, stadions, kosmisks, stacija, tramplīns, klase, organizēt, diskusija, sports, tēma, fotogräfija, metode), which constitute $1 / 5$ of this text.

To investigate the comprehension of foreign words, Form 1 pupils (in Lielupe and Pumpuri secondary schools) were offered two lists of words for foreign word assessment. The first list is established based on foreign words use in the magazine 'Barbie' (12/2007), the second list supplies foreign words which are included in the text-book "Mazā Zïle" (Form 1). Both the foreign word lists mark as + understand, as - do not understand.

Can you understand the foreign words included in the magazine "Barbie"?

\begin{tabular}{|l|l|l|l|l|}
\hline Oriǵināls- & Noregulēt+ & Forma+ & Želatīns- & Esence- \\
\hline Pseidonīms- & Mandeles (rieksti)+ & Krēms+ & Lakrica- & Šokējošs- \\
\hline Frizūra+ & Šokolāde+ & Konfektes+ & Konditoreja- & Komplekts+ \\
\hline Maska+ & Torte+ & Glazūra- & Rums- & Salons+ \\
\hline Valsis- & Žurnāls+ & Telefons+ & Interesants+ & Frizieris+ \\
\hline Princese+ & llustrēts- & Fotogrāfs+ & Kabīne+ & Filma+ \\
\hline Aksesuāri- & Oficiāls- & & & \\
\hline
\end{tabular}

Out of 32 foreign words 11 foreign words, i.e., 1/3, were not understood by Form 1 pupils.

Can you understand the foreign words included in the text-book "Mazā Zile"?

\begin{tabular}{|l|l|l|l|l|}
\hline Hokejs + & Halva + & Džinsi + & Lifts + & Fotografēt + \\
\hline Klase + & Teksts + & Ilustrēt - & Ferma - & Lineāls + \\
\hline Ekskursija + & Karafe - & Tunelis + & Fuksija - & Matemātika + \\
\hline Nektārs - & Ovāls + & Treneris + & Konservi + & Karalis + \\
\hline Metāls + & Luksofors + & Helikopters + & Diktore + & Žirafe + \\
\hline Anekdote + & Hameleons - & Kartīte + & Profesija + & Penālis + \\
\hline Halle - & Haizivs + & Džunglj + & Frizūra + & Filma + \\
\hline
\end{tabular}




\begin{tabular}{|l|l|l|l|l|}
\hline Himna + & Hantele - & Futbols + & Nēǵeris + & Vafeles + \\
\hline Humors + & Džemperis+ & Fanta - & Flamings - & Cilindrs - \\
\hline Enciklopēdija - & Mūzika + & Komisija - & Sports + & Argo - \\
\hline Vizuāls - & Narcise - & Krokuss - & & \\
\hline
\end{tabular}

Out of 53 foreign words 17 foreign words, i.e., almost 1/4, were not understood by Form 1 pupils. To investigate the comprehension of foreign words, Form 2 pupils also were offered 2 lists of words to assess foreign words. The first list included the foreign words, which were used in four texts by the magazine "Zilite" (June, July, August, 2008), the second list was created on the basis of the foreign word usage in the text-book "Zïle" (Form 2), beside this list contains only the more rarely used foreign words (their number - 79).

Can you understand the foreign words included in the magazine "Zilīte"?

\begin{tabular}{|c|c|c|c|c|}
\hline $\begin{array}{l}\text { Ornitoloǵija - } \\
\text { Teritorija + } \\
\text { Marts + } \\
\text { Ekonomika - } \\
\text { Elektroenerǵija + } \\
\text { Planēta - } \\
\text { Internets + } \\
\text { Process - } \\
\text { Hipodroms - } \\
\text { Projekts - } \\
\text { Tularēmija - } \\
\text { Parazitēt - } \\
\text { Veterinārais + }\end{array}$ & $\begin{array}{l}\text { Suga + } \\
\text { Migrēt - } \\
\text { Aprīlis + } \\
\text { Populācija - } \\
\text { Nafta - } \\
\text { Monitors - } \\
\text { Tests - } \\
\text { Arheoloǵisks - } \\
\text { Disciplīna + } \\
\text { Konsultants + } \\
\text { Parazītisks + } \\
\text { Efektīvs- } \\
\text { Preparāts - }\end{array}$ & $\begin{array}{l}\text { Gandrs - } \\
\text { Kilometrs + } \\
\text { Informācija + } \\
\text { Koncentrēties- } \\
\text { Gāze + } \\
\text { Mobils - } \\
\text { Muzejs + } \\
\text { Selekcija - } \\
\text { Tarpāns - } \\
\text { Ekosistēma - } \\
\text { Organisks + } \\
\text { Stadija - }\end{array}$ & $\begin{array}{l}\text { Programma - } \\
\text { Izolēts + } \\
\text { Ekoloǵisks- } \\
\text { Resursi - } \\
\text { Ogle + } \\
\text { Telefons + } \\
\text { Faktiski + } \\
\text { Sports + } \\
\text { Maksimāli- } \\
\text { Parazīts + } \\
\text { Konstatēt + } \\
\text { Mēbele + }\end{array}$ & $\begin{array}{l}\text { Sezona + } \\
\text { Populācija- } \\
\text { Hektārs - } \\
\text { Transports + } \\
\text { Plastmasa+ } \\
\text { Šokolāde + } \\
\text { Hronika - } \\
\text { Tūrisms + } \\
\text { Speciāli + } \\
\text { Konkrēts + } \\
\text { Konsultēties+ } \\
\text { Speciālists + }\end{array}$ \\
\hline
\end{tabular}

Out of 62 foreign words 29 foreign words, i.e., almost 1/2, were not understood by Form 2 pupils.

Can you understand the foreign words included in the text-book "Zile"?

\begin{tabular}{|c|c|c|c|}
\hline Simpātijas+ & Sinonīms - & Arheologs- & Meliorators+ \\
\hline Flomāsters+ & Arhivārs - & Mēness + & Dinozaurs + \\
\hline Protoceratops- & Pterozaurs- & Mēnesis + & Fragments + \\
\hline Emblēma - & Idille - & Difterija- & Grupēt + \\
\hline Grifs - & Prērija - & Buldogs+ & Ingvers - \\
\hline Kojots- & Amarillis- & Ilustrācija+ & Hronists- \\
\hline Diktāts + & Dialogs+ & Kondors- & Cinerārija- \\
\hline Abonents- & Dalmācietis- & Pulverizators- & Propoliss- \\
\hline Komandējums+ & Noformēt+ & Žurnālists+ & Alpīnists+ \\
\hline Badmintons+ & Baravika+ & Enciklopēdija+ & G̦erbonis+ \\
\hline G̦erānija- & Humoristisks+ & Himna+ & Intervija+ \\
\hline Kaktuss+ & Komponists+ & Komikss+ & Loto+ \\
\hline Penālis+ & Recepte+ & Simbols- & Skulptūra+ \\
\hline Sams- & Akācija+ & Aplicēt- & Čempions+ \\
\hline Domino+ & Drakons+ & Dežurants+ & Elastīgs+ \\
\hline Figūriņa+ & Filmiņa+ & Kombinācija- & Hokejs+ \\
\hline Japāṇi+ & Kadrs (filma)+ & Partneris+ & Pikniks+ \\
\hline Grāds+ & Indiānis+ & Ilustrācija+ & Ilustrēt+ \\
\hline Konstrukto & Krokusin,š- & Konflikts+ & Kondors- \\
\hline Komplekts+ & Lokomotīve+ & Magnēts+ & \\
\hline
\end{tabular}


Out of 79 more rarely used foreign words Form 2 pupils could not understand 27 foreign words, i.e., almost $1 / 3$.

As proved by Forms 1 and 2 pupil answers, the comprehensions of foreign words often cause them difficulties. The teachers admit that the meanings of many foreign words are not always clear to the children; therefore explanation of the meanings of such words is necessarily included into the education process. The difficulties are also caused by the pronunciation and spelling of the foreign words (for example, instead of the foreign words like: helikopters, tetovejums, propelleris, tramvajs, krokodils, žirafe, automobilis, koridors the children use: hopteris, heletokteris, tetējums, kodidors, kokoko, žirape, tramis etc.). The teachers claim that they do not know how to teach foreign words to the children, as up to the present the methodology for the teaching of foreign words is not developed. They consider that foreign words are necessary for learning texts, but in a limited number, so that they do not interfere with the perception of the idea manifested by the text.

The text-books for Forms $1-2$ include both the most often used as well as more rarely used foreign words (see table No 1).

Table 1

Usage of foreign words in text books

\begin{tabular}{|l|c|c|c|c|}
\hline \multicolumn{1}{|c|}{ Text-books } & $\begin{array}{c}\text { Foreign words } \\
\text { in total }\end{array}$ & $\begin{array}{c}\text { Explanations of } \\
\text { foreign words } \\
\text { (number) }\end{array}$ & $\begin{array}{c}\text { Most often used } \\
\text { foreign words } \\
\text { (\% out of total } \\
\text { number) }\end{array}$ & $\begin{array}{c}\text { More rarely used } \\
\text { foreign w. } \\
\text { (\% out of total } \\
\text { number) }\end{array}$ \\
\hline $\begin{array}{l}\text { Paegle, Dz. (1997). } \\
\text { Vārds: Lasāmā grāmata } \\
\text { un ievadījums valodas } \\
\text { mācībā 1. klasē } \\
\text { R.: Zvaigzne ABC. }\end{array}$ & 52 & 3 & 23.1 & 17.3 \\
\hline $\begin{array}{l}\text { Mazā Zïle. 1. klasei (2005). } \\
\text { R.: Zvaigzne ABC. }\end{array}$ & 54 & - & 35.8 & 30.2 \\
\hline $\begin{array}{l}\text { Zïle. 1. klasei (2005). } \\
\text { R.: Zvaigzne ABC. }\end{array}$ & 94 & 1 & 31.9 & 23.4 \\
\hline $\begin{array}{l}\text { Zïle I, Il dal̦a 2. klasei (2000). } \\
\text { R.: Zvaigzne ABC. }\end{array}$ & 371 & 11 & 16.4 & 21.3 \\
\hline
\end{tabular}

As indicated by data in Chart No 1, in the text-book by Dz. Paegle, there are included 52 foreign words; 3 of the foreign words (paviljons, eskimoss, négeris) are supplied with explanations. There are 12 most often used foreign words (with the word usage frequency $5-\mathrm{n}$ ) and 9 more rarely used foreign words (with the word usage frequency $1-2$ ), for instance, krokodilite, négerēns, terase, pensija, gipsis, želeja etc.

The text-book for Form 1 "Mazā Zīle" includes 53 foreign words; out of them 19 foreign words belong to the most often used and 16 to the more rarely used, for instance, halle, princesite, helikopters, hameleons, zebra, karafe, fuksija, žirafe, diktore, ovāls, argo, vizuäls etc.

The text-book for Form 1 "Zïle" includes 94 foreign words; an explanation is given for one foreign word (profesija - profession). As established, this text-book includes 30 most often used foreign words and 22 more rarely used ones, for instance, enciklopēdija, karaliene, nektārs, apetīte, kg, krokuss, diktors, kristālinš̌, narcise, cilindrs, prezidente, komisija etc. 
The text-book for Form 2 "Zïle" (Parts I, II) includes 371 foreign word; 11 foreign words (for instance, simpätijas, arheologs, meliorators, sinonims, mēness, mēnesis, idille, prērija etc.) are supplied with explanations, 61 are the most often used foreign words and 79 - the more rarely used ones, for instance, arhivārs, emblēma, grifs, hronists, abonents, dalmācietis, dinozaurs, difterija, ingvers, kondors, pulverizators, propoliss, protoceratops, pterozaurs, koijots, amarillis, cinerärija etc.

According to the questionnaire data that were accomplished (in Lielupe and Pumpuri secondary schools), the majority of the foreign words which are supplied with explanations in the text-books, the children could understand, for instance, mēness, mēnesis, kafija, anekdote, analizèt, rekläma, akrobäts, ideja, plakäts, realizèt, reakcija, simbols etc. It proves that for the explanations of the foreign words have been chosen words, which can be perceived by children.

This study may be useful to the teachers as a methodical aid used for teaching foreign words. The teachers from Jürmala schools when introduced with the data of foreign words usage in the texts of the text-books claimed that they encounter major problems exactly when teaching the more rarely used foreign words.

While teaching the vocabulary of the abovementioned type, the teachers must ask the pupils the following questions, whether they understand every foreign word included in the learning text, whether there are such words, which cannot be understood; attention must also be paid to the pronunciation and spelling of the foreign words. The more rarely used foreign words should be read to the children, then they should be given assistance in forming the word combinations, sentences, and told a story; some analytical and creative exercises with the foreign words could be given, so that children could easier acquire the more rarely used foreign words.

Sometimes the texts for Forms $1-2$ (also the explanations supplied for the foreign words, for instance, praksis, akurāt etc.) include other borrowed words such as, dakteris, opaps, omamma, bode, bonbonga, onkulis, brangs, vinnests, vinnēt, bilde etc., which should be classified as barbarisms. They harm the literary language, "decrease qualitative and quantitative aspects of the speaker's vocabulary, way of expression, have impact on the whole language system - phonetics, grammar, lexicon" (Freiberga 2006, 135); therefore, they should be eliminated. As a positive example we can mention, the text-book by Dz. Paegle, which includes the poem "Valoda" [Language] by M. Cielēn. The poem itself, as well as its key words pays attention to the usage of barbarisms - (kurtka, samosvals, bante, davai) in the Latvian language. It claims that there are words not favourable for the language. If the speaker substitutes a word from some other language for a Latvian word, then the language of such a person is ugly. The key word kit supplies an explanation of barbarisms, for instance, kurtka - a word from the Russian language; in Latvian this outfit is called: vejjaka; bante is a word from the German language, in Latvian it is called - lente or saite, for instance, matu lente, pärsienamā saite. In the contemporary circumstances of bilingualism and multilingualism, when Latvian language users have close contacts with diverse languages, in encounter situations, adults (yet mainly adolescents, also children) borrow from other languages unsuitable words or word clusters and bring them into the Latvian language (for instance, pončiks, gonkas, skāde, tūre, kurtka, vot, forši, davai, semočkas, feini, okei etc.).

The use of barbarisms in children's language most often is connected with the desire to express their feelings and emotions (anger, happiness, surprise etc.); therefore exclamation words are often used, which name certain emotional experiences, give a positive or negative assessment of different issues of reality, for instance bāc!, super, baigi, blı in, vau! Those can be words, which name some deviations in child's physical, mental, spiritual, emotional qualities, for instance čukča, duraks, idiņ̌̌ etc.

To establish the qualitative contents of the cildren's vocabulary, students at RTTEMA guided by lecturers D. Markus, I. Freiberga, I. Freidenfelds and V. Kuzina have compiled barbarisms, which are used by preschool age children in their everyday vocabulary when talking to their peers and adults. The compiled materials are shown in table No 2. 
Table 2

Barbarisms in preschool age children's language

\begin{tabular}{|c|c|}
\hline Barbarisms (in Latvian) & Childrens' phrases (in Latvian) \\
\hline $\begin{array}{l}\text { Padjezds, biškin, fiksi, dikti, superīgs, besī, kruts, } \\
\text { dancot, vinnēt, omīte, opaps, beibe, davai, vāruški, } \\
\text { babuḷa, korablītis, puk,ovka, bai - bai (atvadoties), } \\
\text { blıin, o, bože, forši, fufelis, jes, kurtka, n,efigā, okei, } \\
\text { prikols, šiki, točna, vot, šaiba, klıška, baigi u. c. }\end{array}$ & $\begin{array}{l}\text { Ejam uz padjezdu. Es bišk,iñ nosmērējos. } \\
\text { Fiksi aizskriesi pie audzinātājas. Man mājās ir } \\
\text { superīga galda spēle. Tu mani besī ārā. } \\
\text { Tētis teica, ka esmu šodien krutā beibe. } \\
\text { Davai, jaucam ārā māju un cel̦am jaunu. } \\
\text { Man taču cimdu nav, ir tikai vāruški. } \\
\text { Babul̦a, nu nopērc man šito korablīti. } \\
\text { Mamma rīt dabūs pukovku uz Vaivariem. }\end{array}$ \\
\hline
\end{tabular}

These barbarisms are borrowed from adult and elder brothers or sisters, less often from peers language. Children not always perceive their meanings, and they often do not know the respective words in their native language.

Bilingualism and multilingualism does not mean a mechanical mixture of two or more languages, but a permanent co-existence of the languages; therefore children need the basic knowledge about the common and different features of two or more languages, about the positive and negative aspects of interference. As claimed by I. Freidenfelds (Freidenfelds 2006, 142), multilingualism is one of the remarkable features of the age in children's language; to research it, to interpret it positively and expertly means to promote care for the next generation's mental development and about the future of the Latvian language.

\section{Conclusions}

For enrichment and diversification of children's language, borrowings (loans) should be studied because they constitute a significant part of their lexicon and refer to the conceptions of social and political life, science and art.

The borrowings, which are used reasonably and are easy to perceive, serve as good tools for the acquisition of the Latvian language by children; they can serve as switchmen during that stage when a new language is being mastered (for instance, English, Russian, German etc.).

Everyone (especially teachers) must develop the children's linguistic perception, comprehension of the significance of foreign words (also barbarisms) for the Latvian language. Barbarisms in the children's language are used for variation of expressions; they serve as synonyms for native language words.

As shown by the statistical data, in the texts of the text-books (for Forms $1-2$ ), as well as in children's literature texts, the number of the foreign words used is comparatively great; therefore children's perception of the texts may be diminished. The teachers claim that foreign words are necessary in the learning texts, yet in limited numbers, so that they do not disturb the perception of the idea manifested by the text. The education aids, methodological materials based on the findings of the linguists' investigations.

Particular attention should be paid to the methodology of teaching foreign words at the teacher training study programmes.

\section{References}

1. Birznieks, P. (1996). Valodas pievilcība un atbaide [Attractiveness and Inhibition of a Language]. Karogs. Nr. 1, 148. Ipp. (in Latvian).

2. Freiberga, I. (2006). Dzimtās valodas devalvācija un bērna attīstība pirmsskolas vecumā empīrisko vērojumu un teorētisko atziṇu aspektā [Devaluation of the Native Language and the Child's Development During the Pre- 
school Age as Seen from the Point of View of Empirical Observations and Theoretical Conclusions]. In: RPIVA III Starptautiskās zinātniskās konferences materiāli „Teorija praksei mūsdienu sabiedrības izglīīibā”(135. Ipp.). Rīga: RPIVA (in Latvian).

3. Freidenfelds, I. (2006). Bērnu vairākvalodỉba kā laikmeta zīme [Children's Multilingualism as a Mark of the Epoch]. In: RPIVA III Starptautiskās zinātniskās konferences materiāli „Teorija praksei mūsdienu sabiedrības izglìīibā" (142. Ipp.). Rīga: RPIVA (in Latvian).

4. Kaṇepēja, R. (2003). lepazišanās ar apkärtni. Literatūra. Runas attīstī̌ana. Rakstīt un lasitmācišana. Es gribu iet skolā [Getting Introduced to the Neighbourhood. Literature. Speech Development. Teaching to Write and Read. I Want to Go to School]. Rīga: LU, 58 Ipp. (in Latvian).

5. Kuzina, V. (1996). Bērnu vārdu krājuma bagātināšanas iespējas pirmsskolā un sākumskolā [Possibilities to Enrich Children's Vocabulary in Preschool and Primary School]. In: New dimensions in the development of society. Jelgava: LLU, 260. Ipp. (in Latvian).

\section{Prof. Dr. philol. Viktorija Kuzina}

Riga Teacher Training and Educational Management Academy

Address: Imantas 7. linija 1, Riga, LV-1083, Latvia

Phone: (+371) 26770085

E-mail:viktorija.kuzina@rpiva.Iv 